SECTION 7. Mechanics and machine construction.

Seymur Latif oglu Hasanov

Ph.D, post-graduate Azerbaijan Technology University, Ganja, Azerbaijan s-hasan@hotmail.com

\title{
ABOUT INNOVATIVE BASIS OF RESEARCH OF CONSTRUCTIVE PARAMETERS OF PLANT FOR DOSE OF TANNER MATERIALS IN A FOOD INDUSTRY
}

\begin{abstract}
This scientific article is dedicated to the theoretical grounding of constructive parameters of plant for dose of tanner materials in a food industry on the basis of innovative approach and methods. In scientific work also has given information on use of this plant in other technologic processes.
\end{abstract}

Key words: new technologic plant, food industry, tanner materials, Ganja.

Citation: Hasanov SL (2014) ABOUT INNOVATIVE BASIS OF RESEARCH OF CONSTRUCTIVE PARAMETERS OF PLANT FOR DOSE OF TANNER MATERIALS IN A FOOD INDUSTRY. ISJ Theoretical \& Applied Science 8 (16): 1-3.

\section{Introduction}

The food industry sector has special importance in the economy of the country. Thus, more than half of the population living in rural areas of the country, providing employment, food production, raw materials to achieve greater economic efficiency, have high environmental and quality of food products, exporting products to the developed countries as a result of new technologies and technical means to achieve formation and reliable supply of food is of great importance [1-2]. In addition to the above-mentioned and other positive characteristics, there are problems to be solved in this field. In this regard, the technological and economic performance of the food industry in innovative technologies and the demand for infrastructure is no exception. Taking into account the above-mentioned technology and hardware complex at great economic cost of imports, currently used by technical means such as technological, operational, environmental and economic indicators are low and then the problem seems to be more and more pronounced. With the introduction of innovative technologies and technical means in the country's food production facilities can be a foundation for the reconstruction of the solution to the problem.

\section{Materials and methods}

Our goal is to continuously bulk materials in the food industry for a couple of division into equal parts to create a dosing device is of particular importance in this respect. In order to obtain a high quality product components, which form the basis for the precise dosing of the most important technological processes in production of bakery products is one of dosing.

The main raw material for bakery flour, water, sugar, salt, butter, milk, eggs, ripples, flavored and color items. Therefore, it is important to separate components. The shape of the theoretical and practical research, design parameters and operating conditions basis, the invention of a new device has been created [3-5].

As you can see from the image device operational dosing schedule even distribution of bulk material dosing device, which is used in several places in the right side of the pyramid is linked with the number of members. As can be seen from the number of faces in the right side of the pyramid schemes, as well as the side faces of the forms (linear or curvilinear), choosing the distribution of the quality of the material is aimed. 
Now the consumption norm (for each part of the material is divided) is connected to a dosing device a scheme design parameters (picture 1) as seen in the bulk material is divided into sections, except for one live cut (the window).

\section{Discussion of results}

The mass of the dosing material, except that the live crowd cut (taking into account that the area of the proposed dispersal device installed in the window at the bottom of the body, the inner diameter of the ring-shaped parts using a variety of, in other words, the output window at the bottom of the pyramid, the height of the body dispersal device various values installed (dispersal device by changing the state of the body along the vertical axis with respect to the pyramid), the dosing material mass can be solved easily.

The proposed solution to the issue is the fact that, at the lower part of the windows, and the dispersal of various parameters at the window frame to cover the body of the dispersal device placed symmetrically with respect to each other down the side of the ring-shaped portion and a seat in the kinematics of the fact that the pyramids were used properly, the spreading out of the office window at the bottom of the body of the pyramid-shaped units of various heights and side faces of hoop a variety of different internal diameter of the surface flatness of linear and curvilinear incision pyramids can also be used properly.

The appearance of the corresponding dispersal device. 1, the spreading out of the office window of the body and its built-in, with a variety of built-in relationship with a combination of groove diameter (which is the same as the outer diameter) ring-shaped parts with various values of the height of the pyramid (Hi) on fig. 1 high situation, fig. 2 from AA; BB and CC images on fig. 1, material is removed from the field of live cut dependence on dispersal device to determine the other parameters are given in the schemes fig. 1 and fig. 2.

Dispersal device structure is as follows: dispersal device, which in the bulk material, item 3 out of shape at the bottom of the window, but the inner diameter of the outer diameter of the thread with a combination of different parts of the ring-shaped ring 4 of 4 could be placed symmetrically with respect to the seat is placed on the lower side, with the kinematic 2 depressed the pyramids in the pyramid formed by the side of his face in the ring live through the incision (Figure 1) from the right side of the four faces of the pyramid-shaped portion of the ring created by the bulk of the material is removed from the segment of a circle-shaped pieces of Gord live incision [Fiseq (Hi)] (fig. 1), but both are listed), except in the case of the bulk material contained in a compact $6.8-2$ to fill the pyramid.

\section{Conclusion}

1. The mass of the dosing material, except that the live crowd cut (taking into account that the area of the proposed dispersal device installed in the window at the bottom of the body, the inner diameter of the ring-shaped parts using a variety of, in other words, the output window at the bottom of the pyramid, the height of the body dispersal device various values installed (dispersal device by changing the state of the body along the vertical axis with respect to the pyramid), the dosing material mass can be solved easily.

2. The working principle of the device is performed in the following sequence of dispersal: dispersal device before releasing the work into several equal sharing of material and to regulate the flow rate, which is the same number in the right side of the face of the pyramid, and the ring-shaped part 4 is 2 . The bulk of the material chosen for the part of the body in the form of a ring-shaped cover 3 in 1 is attributed to a combination of groove, compared to the required height of the pyramid Hi installed 2.

3. Thus, theoretically justified by the performance of the proposed new processing plant for further proof of the effectiveness of the application process.

4. Application importance of this plant is high on the basis of research of innovative technologies and methods. 


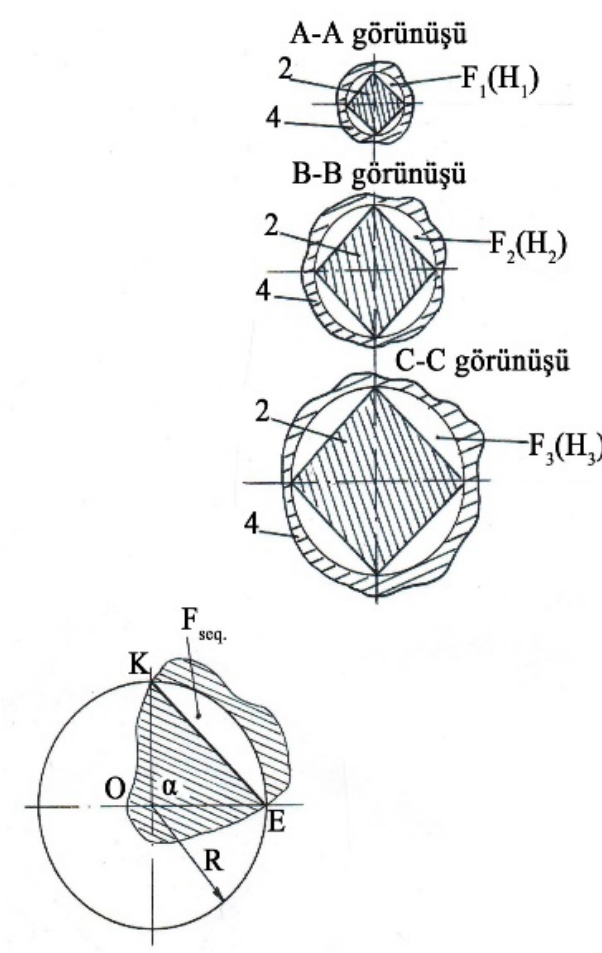

Figure 1.

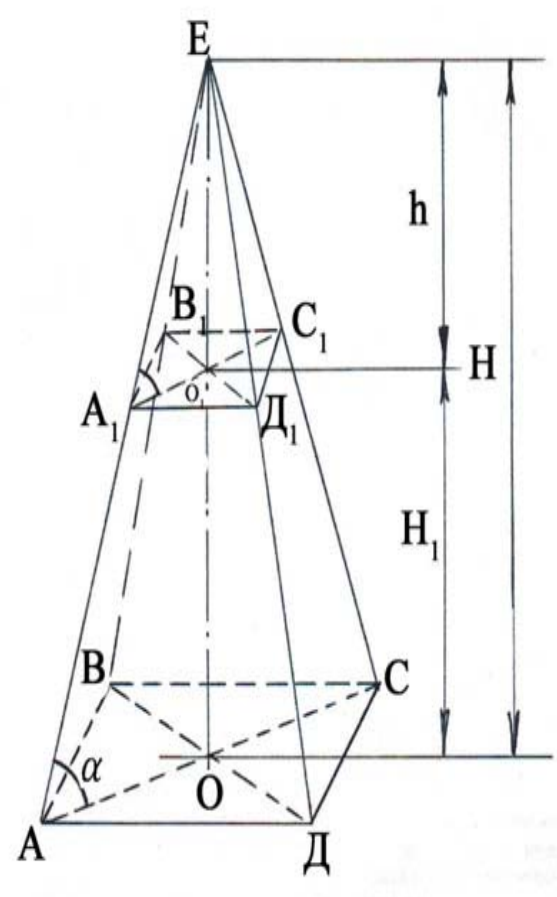

Figure 2.

Picture 1 - Parameters of schemes fig. 1 and fig. 2.

\section{References:}

1. Məlikov ӘQ, Həsənov SL (2009) Qənnadı məmulatları istehsalında istifadə olunan əsas ekstruder qurğularının mühüm texniki parametrlərinin tədqiqi, AMEA Gəncə Regional Elmi Mərkəzin Xəbərlər məcmuəsi, No 35, pp.88-90.

2. Azarov BM, Aret VA (1978) Inzhenernaya reologiya pischevyh proizvodstv, MTIPP, Moscow, $112 \mathrm{p}$.

3. Məlikov ӘQ (2007) Şnekli işçi orqanlı dozalaşdırıcının əsas parametrlərinin tədqiqi, AMEA Gəncə Regional Elmi Mərkəzin Xəbərlər məcmuəsi, No 27, pp. 74-76.

4. (2003) Maşın detalları və konstruksiya etmənin əsasları, Bakı: Təhsil.

5. Məlikov ӘQ, Həsənov SL (2011) Ekstruziya ilə formalayıcı maşının əsas parametrlərinin tədqiqinə dair, Gəncə Dövlət Universitetinin Elmi xəbərləri. Fundamental, humanitar və təbiət elmləri seriyas1, No 2, pp.32-35.

6. Məlikov ӘQ, Həsənov SL (2013) Yeyinti sənayesində səpələnən materialların dozalaşdırılması üçün qurğunun konstruktiv parametrlərinin nəzəri əsaslandırılması, AMEA Gəncə Bölməsinin Xəbərlər məcmuəsi, No 52, pp. 130-143. 